\title{
Asthma referrals: a key component of asthma management that needs to be addressed
}

This article was published in the following Dove Press journal:

Journal of Asthma and Allergy

25 July 2017

Number of times this article has been viewed

\author{
David Price ${ }^{1,2}$ \\ Leif Bjermer ${ }^{3}$ \\ David A Bergin ${ }^{4}$ \\ Rafael Martinez ${ }^{5}$ \\ 'Centre of Academic Primary Care, \\ University of Aberdeen, Aberdeen, \\ UK; ${ }^{2}$ Observational and Pragmatic \\ Research Institute, Singapore; \\ ${ }^{3}$ Department of Respiratory Medicine \\ and Allergology, Lund University, Lund, \\ Sweden; ${ }^{4}$ Novartis Ireland Limited, \\ Dublin, Ireland; ${ }^{5}$ Novartis Pharma AG, \\ Basel, Switzerland
}

Correspondence: David Price Academic Primary Care, Division of Applied Health Sciences, University of Aberdeen, Polwarth Building, Foresterhill, Aberdeen, AB25 2ZD, UK

Tel +65 68029724

Email dprice@opri.sg

\begin{abstract}
Heterogeneity of asthma and difficulty in achieving optimal control are the major challenges in the management of asthma. To help attain the best possible clinical outcomes in patients with asthma, several guidelines provide recommendations for patients who will require a referral to a specialist. Such referrals can help in clearing the uncertainty from the initial diagnosis, provide tailored treatment options to patients with persistent symptoms and offer the patients access to health care providers with expertise in the management of the asthma; thus, specialist referrals have a substantial impact on disease prognosis and the patient's health status. Hurdles in implementing these recommendations include lack of their dissemination among health care providers and nonadherence to these guidelines; these hurdles considerably limit the implementation of specialist referrals, eventually affecting the rate of referrals. In this review, recommendations for specialist referrals from several key international and national asthma guidelines and other relevant published literature are evaluated. Furthermore, we highlight why referrals are not happening, how this can be improved, and ultimately, what should be done in the specialist setting, based on existing evidence in published literature.
\end{abstract}

Keywords: asthma, disease management, specialization, primary care physicians, referral

\section{Introduction}

Asthma is a chronic inflammatory disease of the airway that affects between 235 and 300 million people worldwide, with $\sim 250,000$ annual deaths worldwide attributed to this disease. ${ }^{1,2}$ However, asthma is not a simple airway disease; it is heterogeneous and associated with a range of phenotypes related to age of onset, triggers and type of inflammation (eosinophilic, neutrophilic and pauci-granulocytic phenotypes), and can be further defined on the basis of endotypes. ${ }^{3,4}$ Furthermore, asthma-related symptoms (such as shortness of breath, chest tightness, cough and wheezing that can vary over time and in intensity, together with variable expiratory airflow limitation) are shared with other conditions such as acute and long-term cardiovascular, metabolic, psychologic/ psychiatric and other respiratory conditions. Owing to the complexity of the disease, certain patients with asthma will require a referral to an asthma specialist to address certain aspects of their condition. Such a referral can have a significant impact on the patient's health status. Currently, numerous guidelines are available that provide guidance on when a patient with asthma should be referred to a specialist. For optimal management of these patients, it is important that guideline recommendations for specialist referrals are implemented fully and consistently. In this regard, an overview of the current practice of specialist referrals, possible hurdles in the implementation of 
referrals and possible strategies for improved rate of referrals would be helpful. This review explores the criteria set forth as reasons for referring patients to specialists from various guidelines/strategy documents and how these referrals are utilized in the management of asthma patients.

\section{Methods for compiling asthma guidelines/strategy recommendations for specialist referral}

In order to compile asthma guidelines that would be reviewed, a four-step process was utilized. All well-documented international and national guidelines were obtained (Figure 1). A review of the literature was also carried out by searching the PubMed database (from 1995 to 2016) using the search term "asthma guidelines" and restricting the article type to "guideline" (Figure 1). The retrieved publications from this search were manually reviewed and nonrelevant publications were excluded based on several criteria as outlined in Figure 1. The International Primary Care Respiratory Group asthma guideline database was also searched for national asthma guidelines (Figure 1). Finally, once the asthma guidelines/ consensus documentations were identified by the methods previously described, subsequent searches were conducted using the Google search engine to establish if updated versions existed (Figure 1).

For this review, literature searches were restricted to guidelines, as previously stated, or manuscripts in English language; limited information from regional guidelines has also been included due to their international impact (e.g., Spanish Guideline on the Management of Asthma [GEMA] and the Japanese asthma guidelines). Using the common themes from the guidelines/strategy documents that specialists can play a pivotal role in all aspects of asthma management, all the guidelines/strategy documents criteria/

International and national guidelines

GINA (adult and for children 5 years or younger), NAEPP EPR-3, PRACTALL consensus report, ICON on pediatric asthma, AAAAI practice parameters for the diagnosis and treatment of asthma and AAAAI consultation and referral guidelines $(n=7)$

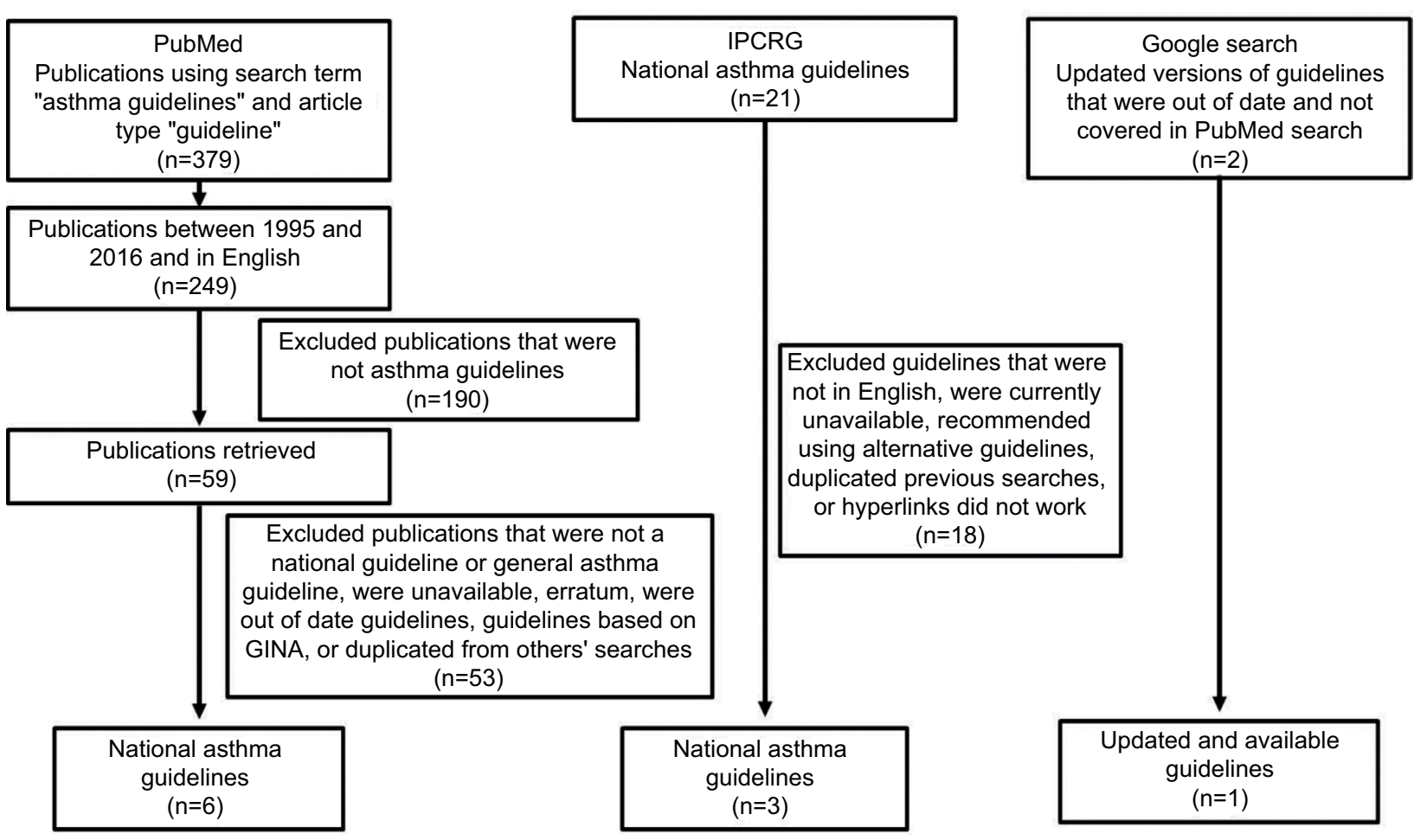

Figure I Guideline selection process.

Abbreviations: AAAAI, American Academy of Allergy Asthma and Immunology; EPR-3, Expert Panel Report-3; GINA, Global Initiative for Asthma; ICON, International Consensus; IPCRG, International Primary Care Respiratory Group; NAEPP, National Asthma Education and Prevention Program; PRACTALL, Practical Allergy. 
recommendations for referrals were examined under four categories: 1) diagnostic uncertainty, 2) asthma severity and high-risk patients, 3) use of corticosteroid treatment (high doses, long-term use and side effects) and 4) the use of addon specialist therapy (biologics). Tables 1 and 2 summarize the results of the compiled guidelines/strategy documents (specialist referral recommendations based on guideline and evidence) for adults and children, respectively.

\section{Asthma guidelines as sources for indications for specialist referrals}

Global and national guidelines aim to improve the diagnosis and management of asthma and ensure that the best practice is implemented consistently. The Global Initiative for Asthma (GINA) has developed a detailed recommendation on the global strategy for asthma management, but because it is only a strategy, the indications for referral may vary due to variations across health care systems. ${ }^{5}$ The GINA strategy is designed to be adapted in order to improve its implementation within the local health care systems or to increase its use for a particular health care professional (HCP) ${ }^{6,7}$ The national guidelines include the British Thoracic Society (BTS) asthma guideline in the $\mathrm{UK},{ }^{8}$ the National Asthma Education and Prevention Program (NAEPP) Expert Panel Report-3 in the USA, ${ }^{9}$ GEMA in Spain, ${ }^{10}$ the Japanese asthma guidelines ${ }^{11}$ and the South African guideline. ${ }^{12}$ Guidelines that address asthma management in children include the NAEPP, the Practical Allergy (PRACTALL) consensus report, the GINA strategy document on asthma management and prevention in children aged 5 years and younger ${ }^{5,9,13}$ and the International Consensus on pediatric asthma, ${ }^{14}$ with some countries, such as South Africa and Japan, having specific national guidelines. ${ }^{15,16}$ Adherence to asthma guidelines/strategy documents, such as the GINA strategy, has been shown to improve the quality of life ${ }^{17}$ and decrease the morbidity and mortality associated with asthma. ${ }^{18}$

\section{Guideline and strategy documents recommendations for specialist referrals \\ Diagnostic uncertainty}

Asthma diagnosis could be confounded by a lack of access to diagnostic equipment, which is also a reason to seek referral. Several of the guidelines confirm an uncertain diagnosis of asthma as a reason to refer patients to a specialist, except for the PRACTALL consensus report ${ }^{13}$ and the Japanese guideline for children ${ }^{16}$ (Table 2).
Several factors aid asthma diagnosis, such as a carefully recorded history, and clinical and diagnostic assessments (spirometry and biomarkers), and all of the guidelines presented in Table 1 allude to these to some extent. GINA recommends spirometry as the preferred diagnostic test for asthma, whereby measurements of airflow limitation, reversibility or bronchial challenge are also used to establish a diagnosis of asthma, ${ }^{5}$ and the involvement of a specialist can result in better access to this tool. ${ }^{19}$ More recently, fractional exhaled nitric oxide (FeNO) has been identified as another diagnostic tool for establishing an asthma diagnosis; ${ }^{20}$ however, depending on the health care system, not all necessary tests (e.g., spirometry, FeNO, hyperresponsiveness) may be available in primary care facilities, and BTS asthma guideline clearly indicates that referral to specialist should be sought should such diagnostic tests not be available in primary care. ${ }^{8}$ Furthermore, discrepancy between guidelines and strategy documents exists on such diagnostics tools. An example of this would be the test for FeNO, where GINA states that this test has not been established as being useful in making a diagnosis of asthma. ${ }^{5}$ On the other hand, in the recent BTS guidelines, a positive FeNO test increases the probability of asthma but a negative test does not exclude asthma. ${ }^{8}$

A recent real-life study demonstrated that using a single test alone was not optimal for an accurate diagnosis, but rather a combination of multiple diagnostic tests in a specialist setting resulted in an increase in diagnostic accuracy, and determined that $81 \%$ of asthma cases could be confirmed objectively. ${ }^{21}$ Diagnostic uncertainty in asthma is evident from the literature, as there is conflicting evidence on asthma being underdiagnosed ${ }^{22,23}$ or overdiagnosed, ${ }^{24-26}$ suggesting that the correct or accurate diagnosis of asthma, especially in children, ${ }^{27}$ remains an issue among physicians. Clinical symptoms of asthma (e.g., cough and wheezing) do not definitively confirm an asthma diagnosis, especially in children. ${ }^{5,9,13}$ Also, there is variability among physicians in identifying the standard primary symptoms of asthma. ${ }^{28}$ Interestingly, the GINA strategy for children under 5 years of age suggests that several key indications should lead to a referral for further diagnostic investigations, such as therapeutic trials of inhaled medication; testing for atopy; chest X-ray; spirometry in children 4-5 years of age; FeNO; and risk profiling tools, for example, asthma predictive index (Table 2). ${ }^{5}$ The American Academy of Allergy Asthma and Immunology (AAAAI) consultation and referral guidelines also suggest that patients with respiratory symptoms who have a normal lung function should be referred to an immunologist/allergist for a methacholine challenge test. ${ }^{29}$ For patients with allergic 
Table I Guideline recommendations for referral of adult asthma patients to a specialist

\begin{tabular}{|c|c|c|c|c|}
\hline \multirow[b]{2}{*}{ Guideline } & \multicolumn{4}{|c|}{ Situations indicated for specialist referral } \\
\hline & Diagnostic uncertainty & High-risk patients & $\begin{array}{l}\text { Corticosteroid treatment } \\
\text { (high dose, long-term use } \\
\text { and side effects) }\end{array}$ & $\begin{array}{l}\text { Add-on specialist } \\
\text { treatment }\end{array}$ \\
\hline $\begin{array}{l}\text { GINA: global } \\
\text { strategy for asthma } \\
\text { management and } \\
\text { prevention }(2016)^{5}\end{array}$ & $\begin{array}{l}\text { Difficulty in confirming } \\
\text { the diagnosis of asthma } \\
\text { - Patient has symptoms } \\
\text { of chronic infection } \\
\text { or features suggesting } \\
\text { a cardiac or other } \\
\text { nonpulmonary cause } \\
\text { (immediate referral } \\
\text { recommended) }\end{array}$ & $\begin{array}{l}\text { - Persistent uncontrolled asthma or } \\
\text { frequent exacerbations, or low lung } \\
\text { function despite correct inhaler } \\
\text { technique and good adherence with } \\
\text { step } 4 \text { treatment (moderate or high- } \\
\text { dose ICS/LABA) } \\
\text { - Symptoms suggesting complications } \\
\text { or subtypes of asthma } \\
\text { - Patient has frequent asthma-related } \\
\text { health care utilization } \\
\text { - Any risk factors for asthma-related } \\
\text { death }\end{array}$ & $\begin{array}{l}\text { - Evidence of, or risk of, } \\
\text { significant treatment side } \\
\text { effects } \\
\text { - Step } 5 \text { treatment, referral } \\
\text { for specialist investigation } \\
\text { and consideration of add-on } \\
\text { treatment } \\
\text { - Need for long-term OCS } \\
\text { use } \\
\text { - Frequent courses of OCS } \\
\text { (two or more courses a } \\
\text { year) }\end{array}$ & $\begin{array}{l}\text { - Omalizumab or } \\
\text { mepolizumab } \\
\text { treatment for } \\
\text { patients who are } \\
\text { uncontrolled at step } \\
4 \text { (moderate or high- } \\
\text { dose ICS/LABA) }\end{array}$ \\
\hline $\begin{array}{l}\text { AAAAl practice } \\
\text { parameters for } \\
\text { the diagnosis } \\
\text { and treatment } \\
\text { of asthma }(1995)^{29}\end{array}$ & $\begin{array}{l}\text { - For identification of } \\
\text { allergens or other } \\
\text { environmental factors } \\
\text { that may be causing the } \\
\text { patients' disease; patients } \\
\text { with asthma must have } \\
\text { access to a thorough } \\
\text { etiologic evaluation and } \\
\text { appropriate diagnostics }\end{array}$ & $\begin{array}{l}\text { - For all asthmatic patients and, in } \\
\text { particular, those with asthma that } \\
\text { is difficult to control, consider a } \\
\text { referral } \\
\text { - Fatality-prone asthmatic patients } \\
\text { requiring special planning, including } \\
\text { monitoring of the patient's course } \\
\text { with regard to the need }\end{array}$ & $\begin{array}{l}\text { - When the patient requires } \\
\text { multiple medications on a } \\
\text { long-term basis } \\
\text { - When frequent bursts of } \\
\text { OCS or daily OCS are } \\
\text { required } \\
\text { - When there is a concern } \\
\text { about the side effects that } \\
\text { have occurred or may occur }\end{array}$ & - NR \\
\hline $\begin{array}{l}\text { AAAAI } \\
\text { consultation and } \\
\text { referral guidelines } \\
(2011)^{29}\end{array}$ & $\begin{array}{l}\text { Patients with respiratory } \\
\text { symptoms suggestive of } \\
\text { asthma, but with normal } \\
\text { pulmonary function } \\
\text { test for a methacholine } \\
\text { challenge test }\end{array}$ & $\begin{array}{l}\text { - Patients with asthma who require ED } \\
\text { care for acute episode } \\
\text { - Uncontrolled asthma } \\
\text { - Severe asthma } \\
\text { - Persistent asthma, particularly } \\
\text { moderate-severe persistent asthma } \\
\text { - Patients with potentially fatal asthma }\end{array}$ & $\begin{array}{l}\text { - Unacceptable side effects of } \\
\text { medications }\end{array}$ & $\begin{array}{l}\text { - Immunomodulator } \\
\text { therapy (anti-lgE) }\end{array}$ \\
\hline $\begin{array}{l}\text { National Asthma } \\
\text { Council Australia } \\
(2015)^{88}\end{array}$ & $\begin{array}{l}\text { Diagnostics tests (FEV } \\
\text { pre-/post-bronchodilator, } \\
\text { reversible airflow } \\
\text { limitation, } \mathrm{FEV}_{\mathrm{I}} / \mathrm{FVC} \\
\text { less than the lower } \\
\text { limit for age, bronchial } \\
\text { provocation test) do not } \\
\text { support asthma diagnosis } \\
\text { - Poor lung function with } \\
\text { few symptoms and after a } \\
\text { 3-month trial of high-dose } \\
\text { ICS }\end{array}$ & $\begin{array}{l}\text { - Uncontrolled asthma on ICS/LABA } \\
\text { combination (moderate to high dose) } \\
\text { - Difficult-to-treat asthma } \\
\text { - If poor lung function persists with } \\
\text { a few symptoms after } 3 \text { months of } \\
\text { higher dose ICS }\end{array}$ & - NR & - NR \\
\hline $\begin{array}{l}\text { British Thoracic } \\
\text { Society }(2016)^{8}\end{array}$ & - Diagnosis unclear & $\begin{array}{l}\text { Patients with the following symptoms: } \\
\text { - Persistent nonvariable breathlessness; } \\
\text { - Monophonic wheeze or stridor; } \\
\text { - Prominent systemic features (myalgia, } \\
\text { fever, weight loss); } \\
\text { - Chronic sputum production; } \\
\text { - Chest X-ray shadowing; } \\
\text { - Marked blood eosinophilia } \\
\text { (>IX109/L); } \\
\text { - Poor response to asthma treatment at } \\
\text { step } 4 \text { prior to proceeding to step } 5 \\
\text { - Severe asthma attack }\end{array}$ & $\begin{array}{l}\text { - Receiving high-does ICS } \\
\text { should be under specialist } \\
\text { care } \\
\text { - Continuous or frequent use } \\
\text { of oral steroids }\end{array}$ & $\begin{array}{l}\text { - Omalizumab } \\
\text { treatment in severe } \\
\text { and difficult allergic } \\
\text { asthma patients who } \\
\text { are on high-dose ICS } \\
\text { and LABA ( }>6 \text { years } \\
\text { of age) }\end{array}$ \\
\hline
\end{tabular}


Table I (Continued)

\begin{tabular}{|c|c|c|c|c|}
\hline \multirow[b]{2}{*}{ Guideline } & \multicolumn{4}{|c|}{ Situations indicated for specialist referral } \\
\hline & Diagnostic uncertainty & High-risk patients & $\begin{array}{l}\text { Corticosteroid treatment } \\
\text { (high dose, long-term use } \\
\text { and side effects) }\end{array}$ & $\begin{array}{l}\text { Add-on specialist } \\
\text { treatment }\end{array}$ \\
\hline $\begin{array}{l}\text { Canadian Thoracic } \\
\text { Society Guideline } \\
\text { Update: Diagnosis } \\
\text { and management } \\
\text { of asthma in } \\
\text { preschoolers, } \\
\text { children and adults } \\
(2012)^{50}\end{array}$ & - NR & $\begin{array}{l}\text { - Children (6-12 years of age) who fail } \\
\text { to achieve control on a medium dose } \\
\text { of ICS } \\
\text { - Uncontrolled asthma in individuals } \\
>12 \text { years of age who are on an } \\
\text { ICS/LABA combination }\end{array}$ & $\begin{array}{l}\text { - In children and adults, the } \\
\text { use of high doses of ICS due } \\
\text { to possible significant side } \\
\text { effects } \\
\text { - In all age groups, frequent } \\
\text { courses of OCS should } \\
\text { prompt referral to a } \\
\text { specialist }\end{array}$ & $\begin{array}{l}\text { - Omalizumab } \\
\text { considered for } \\
\text { patients }>12 \text { years } \\
\text { of age with asthma } \\
\text { poorly controlled } \\
\text { despite high doses of } \\
\text { ICS and appropriate } \\
\text { add-on therapy, with } \\
\text { or without OCS }\end{array}$ \\
\hline GEMA (2009) ${ }^{10}$ & - NR & $\begin{array}{l}\text { - Patients with difficult-to-control } \\
\text { asthma should normally be controlled } \\
\text { at specialized hospital centers by } \\
\text { experienced medical personnel } \\
\text { - When attacks are severe and/or } \\
\text { complications are suspected, patients } \\
\text { must be referred to a hospital ED } \\
\text { - A history of high-risk attacks } \\
\text { - Failure to respond to treatment, } \\
\text { patients must be referred to a } \\
\text { hospital ED }\end{array}$ & - NR & - NR \\
\hline $\begin{array}{l}\text { Ireland asthma } \\
\text { control in general } \\
\text { practice (2012) }\end{array}$ & - Diagnosis is in doubt & $\begin{array}{l}\text { - Post-hospitalization, if patient is } \\
\text { uncontrolled at step } 3 \text { (GINA) }\end{array}$ & - NR & - NR \\
\hline $\begin{array}{l}\text { Japanese guideline } \\
\text { for adult asthma } \\
(201 \mathrm{I})^{6}\end{array}$ & - Diagnosis is challenging & $\begin{array}{l}\text { Patients with underlying } \\
\text { diseases such as AIA, CSS, other } \\
\text { systemic vasculitis, and allergic } \\
\text { bronchopulmonary aspergillosis } \\
\text { - Long-term treatment (ICS, } \\
\text { ICS/LABA, LTRA and omalizumab) } \\
\text { is challenging }\end{array}$ & - NR & $\begin{array}{l}\text { - Long-term } \\
\text { treatment with } \\
\text { omalizumab is } \\
\text { challenging }\end{array}$ \\
\hline $\operatorname{NAEPP}(2007)^{9}$ & $\begin{array}{l}\text { - Signs and symptoms are } \\
\text { atypical or there are } \\
\text { problems in differential } \\
\text { diagnosis } \\
\text { - Additional diagnostic } \\
\text { testing is indicated (e.g., } \\
\text { allergy skin testing, } \\
\text { rhinoscopy, complete } \\
\text { pulmonary function } \\
\text { studies, provocative } \\
\text { challenge and } \\
\text { bronchoscopy) } \\
\text { - Other conditions } \\
\text { complicate diagnosis (e.g., } \\
\text { sinusitis, nasal polyps, } \\
\text { aspergillosis, severe } \\
\text { rhinitis, VCD, GERD and } \\
\text { COPD) }\end{array}$ & $\begin{array}{l}\text { - Patients who had a life-threatening } \\
\text { asthma exacerbation or } \\
\text { hospitalization as a result of an } \\
\text { exacerbation } \\
\text { - Patients who have difficulties } \\
\text { achieving or maintaining control of } \\
\text { asthma (goals of asthma therapy } \\
\text { after } 3-6 \text { months of treatment) and } \\
\text { patient is deemed unresponsive to } \\
\text { treatment by a physician } \\
\text { - Patient requires additional education } \\
\text { and guidance on complications of } \\
\text { therapy, problems with adherence or } \\
\text { allergen avoidance } \\
\text { - Patient requires step } 4 \text { care or higher } \\
\text { (step } 3 \text { for children } 0-4 \text { years of age) } \\
\text { - Consider referral if patient requires } \\
\text { step } 3 \text { care (step } 2 \text { for children } \\
\text { 0-4 years of age) } \\
\text { - Other conditions complicate } \\
\text { asthma (e.g., sinusitis, nasal polyps, } \\
\text { aspergillosis, severe rhinitis, VCD, } \\
\text { GERD and COPD) }\end{array}$ & $\begin{array}{l}\text { Patient has required more } \\
\text { than two bursts of OCS in I } \\
\text { year }\end{array}$ & - NR \\
\hline
\end{tabular}


Table I (Continued)

\begin{tabular}{|c|c|c|c|c|}
\hline \multirow[b]{2}{*}{ Guideline } & \multicolumn{4}{|c|}{ Situations indicated for specialist referral } \\
\hline & Diagnostic uncertainty & High-risk patients & $\begin{array}{l}\text { Corticosteroid treatment } \\
\text { (high dose, long-term use } \\
\text { and side effects) }\end{array}$ & $\begin{array}{l}\text { Add-on specialist } \\
\text { treatment }\end{array}$ \\
\hline $\begin{array}{l}\text { South African } \\
\text { guidelines for the } \\
\text { management of } \\
\text { chronic asthma in } \\
\text { adolescents and } \\
\text { adults }(2007)^{12}\end{array}$ & - Diagnosis is in doubt & $\begin{array}{l}\text { - Increasing severity and treatment } \\
\text { (step 4-5) } \\
\text { - Poor control despite intensive } \\
\text { treatment } \\
\text { - Recurrent exacerbations } \\
>2 \text { per month } \\
\text { - Recent discharge following admission } \\
\text { for severe exacerbation }\end{array}$ & $\begin{array}{l}\text { - OCS dependence } \\
\text { - Significant corticosteroid } \\
\text { side effects }\end{array}$ & - NR \\
\hline $\begin{array}{l}\text { Singapore Ministry } \\
\text { of Health clinical } \\
\text { practice guidelines } \\
\text { on asthma } \\
\text { management } \\
(2008)^{7}\end{array}$ & - Diagnosis is in doubt & $\begin{array}{l}\text { Adults } \\
\text { - Patients who do not achieve good } \\
\text { asthma control despite step } 4 \text { level of } \\
\text { treatment have refractory asthma and } \\
\text { should be reviewed by a specialist } \\
\text { - Severe food allergy } \\
\text { - Refractory patients who do not have } \\
\text { good asthma control despite step } 4 \\
\text { (medium or high-dose ICS plus one } \\
\text { or more "add-on drug") }\end{array}$ & $\begin{array}{l}\text { Adults } \\
\text { - Prolonged high daily dose of } \\
\text { ICS }\end{array}$ & - NR \\
\hline
\end{tabular}

Abbreviations: AAAAI, Academy of Allergy Asthma and Immunology; AIA, aspirin-induced asthma; COPD, chronic obstructive pulmonary disease; CSS, Churg Strauss syndrome; ED, emergency department; FEV, forced expiratory volume in I second; FVC, forced vital capacity; GEMA, Spanish Guideline on Management of Asthma; GERD, gastroesophageal reflux disease; GINA, Global Initiative for Asthma; ICS, inhaled corticosteroid; IgE, immunoglobulin E; LABA, long-acting beta agonist; LTRA, leukotriene receptor antagonist; NAEPP, National Asthma Education and Prevention Program; NR, not reported; OCS, oral corticosteroid; VCD, vocal cord dysfunction.

asthma, the AAAAI practice parameters document indicates that there is a requirement for a referral to establish the target allergen causing asthma by using adequate tests, such as the skin prick test, which require adequate training to perform and interpret results. ${ }^{29}$

Diagnosis of asthma or evaluation of symptoms can be further complicated by the presence of comorbidities, as they may cause respiratory symptoms. ${ }^{30}$ For instance, gastroesophageal reflux disease, sinusitis, allergic rhinitis and nasal polyposis can all result in the worsening of asthma symptoms $^{31}$ and, therefore, may result in some diagnostic uncertainty. NAEPP guidelines highlight that patients with conditions such as sinusitis, nasal polyps, aspergillosis, severe rhinitis, vocal cord dysfunction, gastroesophageal reflux disease and chronic obstructive pulmonary disease should be referred to a specialist. ${ }^{9}$

\section{Asthma severity and high-risk patients}

Some patients with asthma remain uncontrolled despite receiving standard-of-care therapy. ${ }^{32}$ While it might seem appropriate that all patients with uncontrolled asthma should undergo specialist assessment, such a solution would overwhelm any health care system. Therefore, there is a fundamental need to select appropriate uncontrolled asthma patients for referral to a specialist.
A review of the guidelines in Table 1 suggests a substantial variation in recommendations for high-risk patients seeking a referral. Prior to a referral, primary care physicians (PCPs) play a pivotal role in addressing the factors behind poor control (e.g., poor adherence, inhaler technique and comorbidities). ${ }^{5,33}$ The AAAAI practice document suggests that all asthma patients should be considered for a referral, which, as highlighted previously, could result in resource constraints for a health care system. Several of the guidelines recommend that certain patients seek more specialized care (Table 1); for example, GINA indicates that uncontrolled adult patients receiving step 4 asthma therapy (moderate or high-dose inhaled corticosteroid [ICS]/long-acting $\beta_{2}$-agonist or regular asthma-related health care utilization) and frequent exacerbators should be referred for add-on treatment, that is, anti-immunoglobulin E (anti-IgE) treatment or mepolizumab (Table 1). In the guidelines addressing children with asthma, lack of control despite recommended treatment, usually medium- or high-dose ICS, is sufficient to seek a referral (Table 2). GEMA highlights that patients classified as having difficult-to-control asthma should be treated in a specialized setting. ${ }^{10}$ While the BTS guidelines do not specifically mention lack of asthma control as an indicator for a referral in adults, the continuation of certain symptoms and a biomarker (blood eosinophils) are listed as indicators for a 
Table 2 Guideline recommendations for referral of pediatric asthma patients to a specialist

\begin{tabular}{|c|c|c|c|c|}
\hline \multirow[b]{2}{*}{ Guideline } & \multicolumn{4}{|c|}{ Situations indicated for specialist referral } \\
\hline & Diagnostic uncertainty & High-risk patients & $\begin{array}{l}\text { Corticosteroid treatment } \\
\text { (high dose, long-term use } \\
\text { and side effects) }\end{array}$ & $\begin{array}{l}\text { Add-on specialist } \\
\text { treatment }\end{array}$ \\
\hline $\begin{array}{l}\text { GINA: Diagnosis and } \\
\text { management of asthma } \\
\text { in children } 5 \text { years or } \\
\text { younger }(2016)^{5}\end{array}$ & $\begin{array}{l}\text { - Failure to thrive } \\
\text { - Neonatal or very early } \\
\text { onset of symptoms } \\
\text { (especially if associated } \\
\text { with failure to thrive) } \\
\text { - Vomiting associated with } \\
\text { respiratory symptoms } \\
\text { - Continuous wheezing } \\
\text { - Failure to respond } \\
\text { to asthma controller } \\
\text { medications } \\
\text { - No association of } \\
\text { symptoms with typical } \\
\text { triggers, such as viral upper } \\
\text { respiratory tract infection } \\
\text { - Focal lung or } \\
\text { cardiovascular signs, or } \\
\text { finger clubbing } \\
\text { - Hypoxemia outside the } \\
\text { context of viral illness } \\
\text { - Additional reasons } \\
\text { for referral in children } \\
6-11 \text { years: } \\
\text { - Doubts about diagnosis } \\
\text { of asthma }\end{array}$ & $\begin{array}{l}\text { - If symptom control remains } \\
\text { poor and/or flare-ups persist } \\
\text { at step } 4 \text { treatment } \\
\text { - Additional reasons for referral } \\
\text { in children aged 6-II years: } \\
\text { - Symptoms or exacerbations } \\
\text { still remain uncontrolled } \\
\text { despite moderate dose of } \\
\text { ICS (step 4) with correct } \\
\text { inhaler technique and good } \\
\text { adherence }\end{array}$ & $\begin{array}{l}\text { - If side effects of treatment are } \\
\text { observed or suspected at step } \\
4 \text { of treatment } \\
\text { - Additional reasons for referral } \\
\text { in children aged 6-1I years: } \\
\text { - Suspected side effects of } \\
\text { treatment }\end{array}$ & - NR \\
\hline $\begin{array}{l}\text { ICON on pediatric } \\
\text { asthma }(2012)^{14}\end{array}$ & - NR & $\begin{array}{l}\text { Where control cannot be } \\
\text { achieved with the maximum } \\
\text { dose of ICS and additional } \\
\text { medication, with the final } \\
\text { resort being the use of OCS }\end{array}$ & - NR & - NR \\
\hline $\begin{array}{l}\text { Diagnosis and } \\
\text { treatment of asthma in } \\
\text { childhood: PRACTALL } \\
\text { consensus report } \\
(2008)^{13}\end{array}$ & - NR & $\begin{array}{l}\text { - If insufficient control after: } \\
\text { - an increase in ICS dose } \\
\text { ( } 800 \mu g \text { BDP equivalent) } \\
\text { - The addition of LTRA to } \\
\text { ICS or } \\
\text { - The addition of LABA after } \\
\text { checking compliance }\end{array}$ & $\begin{array}{l}\text { Patients requiring high doses } \\
\text { of ICS or doses which are not } \\
\text { licensed }\end{array}$ & - NR \\
\hline $\begin{array}{l}\text { National Asthma } \\
\text { Council Australia } \\
(2015)^{88}\end{array}$ & $\begin{array}{l}\text { - Diagnostic tests (FEV } \\
\text { pre-/post-bronchodilator, } \\
\text { reversible airflow } \\
\text { limitation, bronchial } \\
\text { provocation test and } \\
\text { cardiopulmonary test) } \\
\text { do not support asthma } \\
\text { diagnosis } \\
\text { - Severe upper respiratory } \\
\text { tract infection (severe } \\
\text { rhinitis, nasal polyps) } \\
\text { - Wheezing disorder where } \\
\text { asthma is not confirmed } \\
\text { - Multiple trigger wheeze } \\
\text { - Child is unable to undergo } \\
\text { spirometry (<6 months } \\
\text { old) }\end{array}$ & $\begin{array}{l}\text { - Uncontrolled on ICS high } \\
\text { dose OR low-dose ICS plus } \\
\text { montelukast OR ICS/LABA } \\
\text { (low dose) seek referral }\end{array}$ & - NR & \\
\hline
\end{tabular}


Table 2 (Continued)

\begin{tabular}{|c|c|c|c|c|}
\hline \multirow[b]{2}{*}{ Guideline } & \multicolumn{4}{|c|}{ Situations indicated for specialist referral } \\
\hline & Diagnostic uncertainty & High-risk patients & $\begin{array}{l}\text { Corticosteroid treatment } \\
\text { (high dose, long-term use } \\
\text { and side effects) }\end{array}$ & $\begin{array}{l}\text { Add-on specialist } \\
\text { treatment }\end{array}$ \\
\hline $\begin{array}{l}\text { British Thoracic } \\
\text { Society }(2016)^{8}\end{array}$ & - Diagnosis unclear & $\begin{array}{l}\text { - Symptoms present from birth } \\
\text { or perinatal lung problem } \\
\text { - Excessive vomiting or } \\
\text { posseting, severe upper } \\
\text { respiratory tract infection; } \\
\text { persistent wet or productive } \\
\text { cough, family history of } \\
\text { unusual chest disease, failure } \\
\text { to thrive, nasal polyps } \\
\text { - } 5 \text {-12 years of age, failure } \\
\text { to respond to conventional } \\
\text { treatment, particularly at step } \\
5 \text { (ICS up to } 800 \text { } \mu \text { g/day) } \\
\text { - <5 years of age, uncontrolled } \\
\text { at step } 3 \text { (200-400 mg of ICS } \\
\text { with LTRA) } \\
\text { - <2 years of age, uncontrolled } \\
\text { at step } 2 \text { ( } 200-400 \text { mg ICS) }\end{array}$ & $\begin{array}{l}\text { - Receiving high-dose ICS should } \\
\text { be under specialist care } \\
\text { - Continuous or frequent use of } \\
\text { oral steroids }\end{array}$ & \\
\hline $\begin{array}{l}\text { Canadian Thoracic } \\
\text { Society Guideline } \\
\text { Update: Diagnosis and } \\
\text { management of asthma } \\
\text { in preschoolers, } \\
\text { children and adults } \\
(2012)^{50}\end{array}$ & - NR & $\begin{array}{l}\text { - Children (6-12 years of age) } \\
\text { who fail to achieve control on } \\
\text { a medium dose of ICS } \\
\text { - Uncontrolled asthma in } \\
\text { individuals }>12 \text { years of } \\
\text { age who are on an ICS/LABA } \\
\text { combination }\end{array}$ & $\begin{array}{l}\text { - In children, the use of high } \\
\text { doses of ICS due to possible } \\
\text { significant side effects } \\
\text { - In all age groups, frequent } \\
\text { courses of OCS should } \\
\text { prompt referral to a specialist }\end{array}$ & $\begin{array}{l}\text { - Omalizumab } \\
\text { considered for } \\
\text { patients }>12 \text { years } \\
\text { of age with asthma } \\
\text { poorly controlled } \\
\text { despite high doses of } \\
\text { ICS and appropriate } \\
\text { add-on therapy, with } \\
\text { or without OCS }\end{array}$ \\
\hline $\begin{array}{l}\text { Japanese guideline } \\
\text { for childhood asthma } \\
(2014)^{\prime \prime}\end{array}$ & - NR & $\begin{array}{l}\text { - Uncontrolled patients } \\
\text { with step } 3 \text { (medium ICS } \\
\text { dose) or step } 4 \text { (high-dose } \\
\text { ICS) management strategy }\end{array}$ & - NR & - NR \\
\hline $\begin{array}{l}\text { South African } \\
\text { guidelines for the } \\
\text { management of chronic } \\
\text { asthma in children } \\
(2009)^{12}\end{array}$ & - Diagnosis is in doubt & $\begin{array}{l}\text { - Uncontrolled asthma requiring } \\
\text { level three treatment }(<5 \\
\text { medium dose ICS with LTRA } \\
\text { or }>5 \text { medium to high-dose } \\
\text { ICS/LABA) } \\
\text { - Life-threatening episode } \\
\text { - Frequent hospitalizations or } \\
\text { emergency room visits }\end{array}$ & $\begin{array}{l}\text { - High dose of ICS }(>400 \mu \mathrm{g} / \\
\text { day) } \\
\text { - OCS required regularly }\end{array}$ & $\begin{array}{l}\text { - Omalizumab being } \\
\text { considered an option }\end{array}$ \\
\hline $\begin{array}{l}\text { Singapore Ministry of } \\
\text { Health clinical practice } \\
\text { guidelines on asthma } \\
\text { management }(2008)^{7}\end{array}$ & & $\begin{array}{l}\text { - High-risk asthma with } \\
\text { poor asthma control } \\
\text { - <3 years and requires } \\
\text { moderate to high doses of } \\
\text { inhaled steroids and not } \\
\text { responding as expected }\end{array}$ & $\begin{array}{l}\text { - Requires high-dose steroids, } \\
\text { BDP/BUD } \geq 400 \mu g / \text { day or } \\
\text { fluticasone } \geq 200 \mu g / \text { day or is } \\
\text { on prolonged inhaled steroid } \\
\text { therapy for }>6 \text { months and } \\
\text { remains symptomatic } \\
\text { - A severe acute asthma attack } \\
\text { and requires prolonged or } \\
\text { repeated OCS for control }\end{array}$ & \\
\hline
\end{tabular}

Abbreviations: BDP, beclomethasone dipropionate; BUD, budesonide; FEV , forced expiratory volume in I second; GINA, Global Initiative for Asthma; ICON, International Consensus; ICS, inhaled corticosteroid; LABA, long-acting beta agonist; LTRA, leukotriene receptor antagonist; NR, not reported; OCS, oral corticosteroid; PRACTALL, practical allergy. 
referral. ${ }^{8}$ Furthermore, both AAAAI publications on asthma referrals advise that patients with uncontrolled asthma should be referred to an immunologist/allergist (Table 1). According to the NAEPP and Japanese adult guidelines, patients with other comorbidities that could affect asthma control ${ }^{30}$ constitute a high-risk group and should be referred to a specialist.

Aside from uncontrolled patients, some of the guidelines suggest that other patient cohorts should be referred to a specialist. The South African guidelines for adults and the AAAAI consultation and referral guideline suggest that severe asthma is a reason to seek a specialist referral. The Australian guidelines indicate that patients who have evidence of poor lung function despite the use of a high dose of ICS for 3 months should seek a referral. GEMA recommends that patients who fail to respond to treatment must be referred to a hospital emergency department (ED). ${ }^{10}$ In the case of severe asthma, guideline definitions of severe asthma and subsequent treatment recommendations are widely inconsistent because different guidelines use different criteria to define suboptimal asthma control. ${ }^{34}$ The differences in criteria are broadly centered on interpreting clinical evidence and framing recommendations. For example, there is a lack of clarity on whether patients should go to step 3 or step 4 or even step 5 treatment if they are uncontrolled, clearly indicating that the threshold for change in treatment step is not clear. Currently, this threshold is so broad that approximately over $20 \%$ of patients receiving combination therapy could be referred to a specialist. ${ }^{35}$ In light of the significant consequences of inconsistencies among guideline definitions and recommendations, a common set of validated and clear methods across global and regional guidelines could harmonize treatment recommendations and enable guideline implementation in the management of severe asthma.

Exacerbations are known to have a huge impact on a patient's quality of life, ${ }^{36}$ with asthma control and exacerbation history being predictors of future exacerbations. ${ }^{37}$ Previously, it has been suggested that $20 \%$ of patients with asthma have had an exacerbation requiring hospitalization and these events can account for up to $80 \%$ of the costs associated with asthma. ${ }^{38}$ Specialist care can reduce the number of hospitalizations and the risk of future hospitalizations. ${ }^{39}$ GEMA guidelines suggest that high-risk asthma attacks or when severe asthma attacks occur and complications are suspected as a need to seek a referral to a hospital ED. ${ }^{10}$ GINA, AAAAI and NAEPP guidelines indicate that patients who have frequent asthma-related health care utilization or a hospitalization/ED visit should be considered as high-risk individuals and, therefore, be referred (Table 1). The Irish guidelines follow this suggestion with some more specificity, stating that patients could be referred post-hospitalization if uncontrolled at step $3 .^{6}$ The only other guideline with reference to an exacerbation/hospitalization as a cause for referral is the South African guideline, which recommends that adults who have two or more exacerbations per month are a group who should seek specialist care. ${ }^{12}$ The South African pediatric guideline is less specific in suggesting that frequent hospitalizations are a reason to refer (Table 2).

Furthermore, every year it is estimated that a quarter of a million deaths worldwide are asthma related. ${ }^{2}$ The importance of referrals for patients has been recently highlighted in a British evaluation of asthma deaths, whereby $20 \%$ of deaths investigated were related to avoidable factors associated with referrals (including delays or failure of referral for specialist opinion) and over $50 \%$ of patients were not under specialist supervision prior to their deaths. ${ }^{39}$ Of the guidelines examined in this review, only the GINA, NAEPP and AAAAI referral guidelines specifically recommend that patients who are at risk of an asthma-related death (GINA) or fatal asthma (AAAAI) or fatally prone (NAEPP) should be referred to a specialist (Table 1).

\section{Use of corticosteroid treatment}

Steroids play an important role in the management of asthma in the form of ICS and oral corticosteroids. These therapies have a positive impact on controlling symptoms and exacerbations. ${ }^{40}$ However, there are side effects associated with this treatment, such as growth suppression, ${ }^{41}$ hypothalamicpituitary-adrenal axis suppression in children, ${ }^{42}$ cataracts, ${ }^{43,44}$ diabetes, ${ }^{45}$ and bone density changes and osteoporosis. ${ }^{46,47}$ Similar to patients with chronic obstructive pulmonary disease, there is a suggestion that ICS use is associated with higher risk for asthma patients developing pneumonia or lower respiratory tract infections, particularly when used in high doses. ${ }^{48}$ More recently, it has been demonstrated that morbidity rates were increased for conditions associated with systemic steroid exposure in patients with severe asthma. ${ }^{49}$

Therefore, given the risks associated with this therapy, there is a need to monitor its use. With regard to recommendations regarding the side effects in the guidelines, GINA suggests that any evidence or risk of side effects from treatments is a reason to refer adults or children aged between 6 and 11 years (Table 2). ${ }^{5}$ A similar statement is made by the AAAAI, using the example of oral corticosteroids and ICS in children. ${ }^{29}$ The Canadian guidelines also highlight the use of high-dose ICS in children and its possible side effects as an indication for referral (Table 2). ${ }^{50}$ 
Long-term use of high doses of corticosteroids is associated with the development of systemic side effects. ${ }^{49,51}$ It is evident that there is a high use of ICS in asthma, and some of these patients are not severe enough to require this treatment, as observed in a British study where $90 \%$ of the patients were receiving ICS despite the fact that over 50\% were classified as having intermittent asthma, and thus did not warrant controller therapy..$^{52}$ A specialist referral could provide the opportunity to review the dosage of ICS prescribed, and possibly to step down the dose when asthma control is maintained. GINA further elaborates on seeking a specialist referral at step 5 when there is need for add-on treatment, which is a preferred option to oral corticosteroids, if there is long-term use of oral corticosteroids or frequent use of oral corticosteroids (e.g., two or more courses in 1 year; Table 1). For children with asthma, both the South African and Singaporean guidelines provide more specificity on the doses of ICS prescribed that would justify these patients being referred to a specialist (Table 2). The AAAAI practice document states that long-term use of any medication should be an indication for a referral. ${ }^{29}$

PRACTALL covers the topic of prescribing unlicensed dose of steroids in children as a reason to seek a referral to a specialist (Table 2). Such use of steroids has been documented in an observational study, where $\sim 5 \%$ of children aged between 5 and 11 years and $4 \%$ of children aged $<5$ years were prescribed unlicensed high doses of ICS, which could potentially expose these patients to treatment-related adverse effects. ${ }^{53}$ An examination of the Australian, BTS, Japanese and GINA guidelines for children $\leq 5$ years of age reveals that these guidelines do not offer any recommendations on when to refer patients with corticosteroid use in asthma, despite the fact that some of the recommendations are adapted from guidelines that do cover this topic.

\section{Use of add-on specialist therapies}

Referring a patient to a specialist may allow them access to additional health care resources and add-on therapies, such as omalizumab, which are not available in the primary care setting. A recent Italian and German study highlighted that $12 \%$ of patients who were being treated by PCPs and officebased respiratory consultants were eligible for omalizumab, but were not receiving this therapy. ${ }^{54}$ Access to additional health care resources and treatments not available in the primary care setting could prevent the chronic use of oral corticosteroids by patients, thus reducing their exposure to the associated side effects of this treatment. ${ }^{5}$ This has been well documented with omalizumab, where a reduction in the use of $\mathrm{ICS}^{55-57}$ and oral corticosteroids in adults ${ }^{58}$ and children ${ }^{59}$ was observed. The use of this specialized add-on therapy has only been captured in a few guidelines. GINA specifically recommends asthma treatment to be on the basis of the level of asthma control, and it further suggests referring patients in step 5 (severe asthma) to a specialist, so that they can be assessed for additional add-on treatment, such as anti-IgE therapy or mepolizumab, which is preferred over oral corticosteroids. ${ }^{5}$ The BTS, AAAAI, Canadian, Japanese and South African guidelines also indicate that patients should be referred to a specialist if anti-IgE therapy is being considered. The specialist will also provide a vital checkpoint whereby, when required for certain patients, there would be an appropriate escalation to additional therapies such as omalizumab for severe allergic asthma patients. In the near future, there will be more biologics indicated for use in asthma, such as anti-interleukin (IL)-4/IL-13 (dupilumab), anti-IL13 (lebrikizumab) and new anti-IL-5 therapies (reslizumab and benralizumab) ${ }^{60}$ and guidelines will have to be updated accordingly. The use of biologics will require a broader diagnostic setup, potentially with biomarkers, in order to define eligible patients for each entity, which might only be available in a specialized center. This would allow for more personalized medicine, as well as the involvement of a specialist, which would ensure that they are prescribed to the correct patient population.

\section{Evidence that specialist referrals are not occurring}

Irrespective of the difference in details and information on specialist referral, it is evident that the asthma guidelines and strategy documents provide clear recommendations on when a referral should be sought. However, evidence suggests that there is a lack of specialist referrals or a failure to refer in practice. As highlighted previously, an evaluation of asthma deaths in the UK found that $20 \%$ of deaths investigated were related to avoidable factors associated with referrals..$^{39} \mathrm{~A}$ review of asthma management in the US, based on NAEPP guidelines, observed that the majority of patients were uncontrolled and only $22 \%$ of patients had visited a specialist regarding their asthma care. Approximately 50\% of patients had never visited a specialist. ${ }^{61}$ This is likely to be an important contributor to suboptimal management, given that specialist treatment can result in more favorable outcomes. ${ }^{62}$ It has been shown in a retrospective review of a pediatric asthma population that only $44 \%$ visited an asthma specialist within 12 months of the initial ED visit, contrary to guideline recommendations. ${ }^{63}$ 


\section{Why are guidelines not adhered to and how can adherence be improved?}

Besides documented differences in asthma guideline or strategy documents, the lack of knowledge on key referral guidelines and/or lack of implementation of these guidelines can ultimately impact the rate of referrals. Despite the obvious benefits of guidelines, evidence suggests that both the utilization of and adherence to these documents in the management of patients with asthma among HCPs are poor. ${ }^{6470} \mathrm{~A}$ review of the possible reasons for poor adherence to asthma guideline recommendations highlighted the multifactorial barriers that physicians encounter, which could be grouped into three main areas: lack of physician knowledge about recommendations, inertia toward implementation of guidelines and clinical practice-related difficulties.

The lack of awareness or knowledge of guidelines by physicians is a barrier to physician adherence and implementation. ${ }^{65-70}$ In a study by Pinnock et al, the lack of knowledge of asthma guidelines among HCPs in the UK resulted in a low average score of 5.2 out of 11 in a web-based questionnaire that assessed their familiarity with guideline recommendations. ${ }^{65}$ Aside from knowledge, physicians may also disagree with certain guidelines and, therefore, may not follow the recommendations. ${ }^{69}$ Furthermore, external or practical barriers (e.g., lack of time and limited staff resources) can also impact guideline adherence. ${ }^{70}$ It should also be noted that PCPs encounter patients with different asthma severities and control, and implementation of guideline recommendations needs to be modulated accordingly. ${ }^{71}$ Other significant barriers such as lack of self-efficacy and lack of belief in outcomes of referrals have also been noted. ${ }^{70}$

The lack of adherence to referral guidelines could be overcome with continuing medical education and discussions with colleagues. $^{72}$ A recent study demonstrated that a facilitator-led group self-assessment activity involving physicians led to improved quality of asthma care and adherence to guidelines. ${ }^{73}$ Furthermore, interventions such as decision support tools, feedback and audit, and clinical pharmacy support could improve HCP adherence to asthma guidelines. ${ }^{74}$ Finally, a recent study by Lugtenberg et al highlighted that to implement guidelines, suitable and accepted interventions that are appealing to the targeted physician group need to be identified. ${ }^{75}$

It should be noted that, while guidelines and their implementation have an impact on referrals, there are other unassociated factors that can impact referrals, which have not been addressed in this review. The referral process, in general, may have breakdowns and inefficiencies in terms of decision making, coordination and access to specialty care. ${ }^{76}$ For example, it has been shown that patients utilized other hospital facilities such as ED due to a defective referral system. ${ }^{77}$ Specifically, the referral process has inconsistencies among the initiator and facilitator ${ }^{78}$ as well as the patient. ${ }^{79}$ There could be financial disincentives to refer, especially with regards to physicians with ownership stakes in a practice. ${ }^{80}$ There can also be an inadequate availability of specialists to provide advanced care to patients. ${ }^{81}$

\section{What should be done in the specialist setting?}

The benefits for patients with asthma being referred to specialists should result in several positive outcomes: most importantly, the correct identification of disease to ensure appropriate treatment administration as well as the maintenance of symptom control, and a reduction in health care utilization and associated costs. ${ }^{82}$

Several studies have demonstrated that when patients received care from an asthma specialist, the number of hospitalizations or the chance of these patients being hospitalized was reduced. ${ }^{62,83,84} \mathrm{~A}$ recent study involving children with moderate or severe asthma suggested that improving referral and attendance at asthma specialty clinics (asthma, respiratory or allergy clinic) for these children had the potential to improve clinical outcomes. ${ }^{63}$ Asthma specialists could also provide patients with a more enhanced education, ${ }^{85}$ which is an essential component of asthma management and results in enhanced quality of life of patients. ${ }^{83,85}$ It has been reported that referral to a specialist led to more effective treatment as a higher percentage of specialists consider pharmacotherapies to be essential in asthma management compared with general practitioners. ${ }^{86}$ Overall, specialist referral has been shown to be effective in improving asthma management. ${ }^{71}$

To facilitate appropriate referrals, more frequent monitoring should be considered for patients with moderate and severe persistent asthma. ${ }^{8}$ For example, in patients with an acute asthma attack, a respiratory specialist should follow-up patients admitted with a severe asthma attack for at least 1 year after the admission. Systematic assessment of patients with severe asthma has increasingly been taken up by severe asthma clinics, ${ }^{87}$ which have expertise in diagnosis, assessment of severity, comorbidities, adherence and devices, and individualized treatment of these patients. Guidelines and strategy documents ${ }^{5,8}$ now recommend that all patients with severe persistent asthma or a history of severe exacerbations requiring hospitalization be referred to an asthma specialist or a specialized asthma clinic. 
Patients may have access to additional health care resources and treatments only available in the specialist setting, which could result in more appropriate treatment being administered and prevent the chronic use of oral corticosteroids by patients, thus reducing their exposure to the associated side effects of this treatment. ${ }^{5}$ Furthermore, referring patients with severe or uncontrolled asthma to a specialist also provides a vital checkpoint whereby, when required for certain patients, there would be an appropriate escalation to additional therapies, for example, omalizumab and mepolizumab treatment for severe allergic asthma patients. Such treatments are expensive and involvement of a specialist would ensure that they are prescribed to the correct patient population. Overall, regular follow-up communication between specialists and PCPs should lead to informed assessment of disease control, optimized treatment strategies and improved clinical outcomes in patients.

\section{Conclusion}

The increasing prevalence of asthma has directly increased morbidity, mortality and the economic burden associated with this disease. Despite advances in asthma therapies and development of several guidelines and strategy documents recommending referral of certain patients to a specialist in order to improve their asthma control and reduce health resources utilization, the management of asthma remains suboptimal. To achieve appropriate referrals, there needs to be additional proper dissemination, translation, training, implementation and adherence of appropriate asthma guidelines that suit the health care landscape. Furthermore, an effective specialist referral system requires better coordination between health care providers and patients in different settings, which will allow for a better and more appropriate treatment for patients with asthma. The discrepancy across different asthma guidelines/strategy documents for specialist referrals also needs to be addressed through development of consensus-based strategies. In particular, optimizing referral processes in severe asthma should be given priority by the health care systems in order to minimize the significant morbidity and mortality associated with the disease. Ultimately, an improved process of specialist referrals would benefit patients with asthma with unmet needs in improving their asthma control and reducing health care resource utilization.

\section{Acknowledgments}

The authors thank Rahul Lad, PhD of Novartis for providing medical writing support, which was funded by Novartis
Pharma AG in accordance with Good Publication Practice (GPP3) guidelines.

\section{Disclosures}

Professor David Price has board membership with Aerocrine, Amgen, AstraZeneca, Boehringer Ingelheim, Chiesi, Meda, Mundipharma, Napp, Novartis and Teva Pharmaceuticals; consultancy agreements with Almirall, Amgen, AstraZeneca, Boehringer Ingelheim, Chiesi, GlaxoSmithKline, Meda, Mundipharma, Napp, Novartis, Pfizer, Teva Pharmaceuticals and Theravance; grants and unrestricted funding for investigator-initiated studies (conducted through Observational and Pragmatic Research Institute Pte Ltd) from Aerocrine, AKL Research and Development Ltd, AstraZeneca, Boehringer Ingelheim, British Lung Foundation, Chiesi, Meda, Mundipharma, Napp, Novartis, Pfizer, Respiratory Effectiveness Group, Takeda, Teva Pharmaceuticals, Theravance, UK National Health Service, Zentiva; payment for lectures/speaking engagements from Almirall, AstraZeneca, Boehringer Ingelheim, Chiesi, Cipla, GlaxoSmithKline, Kyorin, Meda, Merck, Mundipharma, Novartis, Pfizer, Skyepharma, Takeda and Teva Pharmaceuticals; payment for manuscript preparation from Mundipharma and Teva Pharmaceuticals; payment for the development of educational materials from Mundipharma and Novartis; payment for travel/accommodation/meeting expenses from Aerocrine, AstraZeneca, Boehringer Ingelheim, Mundipharma, Napp, Novartis and Teva Pharmaceuticals; funding for patient enrollment or completion of research from Chiesi, Novartis, Teva Pharmaceuticals and Zentiva; stock/stock options from AKL Research and Development Ltd which produces phytopharmaceuticals; owns $74 \%$ of the social enterprise Optimum Patient Care Ltd, UK and 74\% of Observational and Pragmatic Research Institute Pte Ltd, Singapore; and is a peer reviewer for grant committees of the Efficacy and Mechanism Evaluation program, Health Technology Assessment, and Medical Research Council. Professor Leif Bjermer has, during the last 5 years, given lectures and/or attended advisory board for the following companies: AKL Research and Development Ltd, AstraZeneca, Airsonette, Chiesi, Boehringer, GlaxoSmith Kline, Meda, Merck, Mundipharma, Novartis and Teva. David A Bergin and Rafael Martinez are employees of Novartis.

\section{References}

1. World Health Organization. Chronic respiratory diseases; Scope: asthma; cited 2014. Available from: http:/www.who.int/respiratory/ asthma/scope/en/. Accessed January 18, 2017.

2. Bousquet J, Khaltaev N, editors. Global surveillance, prevention and control of chronic respiratory diseases: a comprehensive approach. World Health Organization; 2007. Available from: http:/www.who.int/gard/ publications/GARD\%20Book\%202007.pdf. Accessed January 18, 2017. 
3. Cottini M, Asero R. Asthma phenotypes today. Eur Ann Allergy Clin Immunol. 2013;45(1):17-24.

4. Lotvall J, Akdis CA, Bacharier LB, et al. Asthma endotypes: a new approach to classification of disease entities within the asthma syndrome. J Allergy Clin Immunol. 2011;127(2):355-360.

5. Global Initiative for Asthma. Global Strategy for Asthma Management and Prevention. 2016. Available from: www.ginasthma.org. Accessed January 18, 2017.

6. Holohan J, Manning P, Nolan D, National Asthma Programme. Asthma control in general practice, $2^{\text {nd }}$ Edition, 2012. Available from: http://in.bgu.ac.il/en/fohs/communityhealth/Family/Documents/ ASTHMA $\% 20 \% 20$ GINA $\% 20 \% 20 \% 20$ Asthma-Control-GeneralPractice-Guidelines-2012.pdf. Accessed January 18, 2017.

7. Ministry of Health, Singapore. Management of Asthma; 2008. Available from: https://www.moh.gov.sg/content/moh_web/home/Publications/ guidelines/cpg/2008/management_of_asthma.html. Accessed January 18, 2017.

8. British Thoracic Society. BTS/SIGN British guideline on the management of asthma; 2016. Available from: https://www.brit-thoracic.org. uk/standards-of-care/guidelines/btssign-british-guideline-on-themanagement-of-asthma/. Accessed January 18, 2017.

9. National Heart Lung and Blood Institute; National Asthma Education and Prevention Program; US Department of Health and Human Services; National Institutes of Health; Expert panel report 3: Guidelines for the diagnosis and management of asthma; Full report 2007. Available from: https://www.nhlbi.nih.gov/files/docs/guidelines/asthgdln. pdf. Accessed January 18, 2017.

10. Executive Committee GEMA 2009. GEMA 2009 (Spanish guideline on the management of asthma). J Investig Allergol Clin Immunol. 2010;20(Suppl 1):1-59.

11. Ohta K, Yamaguchi M, Akiyama K, et al. Japanese guideline for adult asthma. Allergol Int. 2011;60(2):115-145.

12. Lalloo U, Ainslie G, Wong M, et al. Guidelines for the management of chronic asthma in adolescents and adults. SAfr Pharm J. 2007;49(5):28-41

13. Bacharier LB, Boner A, Carlsen KH, et al. Diagnosis and treatment of asthma in childhood: a PRACTALL consensus report. Allergy. 2008;63(1):5-34.

14. Papadopoulos NG, Arakawa H, Carlsen KH, et al. International consensus on (ICON) pediatric asthma. Allergy. 2012;67(8):976-997.

15. Motala C, Green RJ, Manjra AI, Potter PC, Zar HJ; South African Childhood Asthma Working G. Guideline for the management of chronic asthma in children-2009 update. S Afr Med J. 2009;99(12 Pt 2):898-912.

16. Hamasaki Y, Kohno Y, Ebisawa M, et al. Japanese guideline for childhood asthma 2014. Allergol Int. 2014;63(3):335-356.

17. Bateman ED, Bousquet J, Keech ML, Busse WW, Clark TJ, Pedersen SE. The correlation between asthma control and health status: the GOAL study. Eur Respir J. 2007;29(1):56-62.

18. Rodriguez-Trigo G, Plaza V, Picado C, Sanchis J. El tratamiento según la guía de la Global Initiative for Asthma (GINA) reduce la morbimortalidad de los pacientes con asma de riesgo vital [Management according to the Global Initiative for Asthma guidelines of patients with near-fatal asthma reduces morbidity and mortality]. Arch Bronconeumol. 2008;44(4):192-196. Spanish.

19. Gershon AS, Victor JC, Guan J, Aaron SD, To T. Pulmonary function testing in the diagnosis of asthma: a population study. Chest. 2012;141(5):1190-1196.

20. National Guideline Clearinghouse; Agency for Healthcare Research and Quality; US Department of Health and Human Services. Guideline summary: Measuring fractional exhaled nitric oxide concentration in asthma: NIOX MINO, NIOX VERO and NObreath. Available from: https://www.guideline.gov/summaries/summary/48533/measuringfractional-exhaled-nitric-oxide-concentration-in-asthma-niox-minoniox-vero-and-nobreath. Accessed January 18, 2017.

21. Backer V, Sverrild A, Suppli Ulrik C, Bødtger U, Seersholm N, Porsbjerg C. Diagnostic work-up in patients with possible asthma referred to a university hospital. Eur Clin Respir J. 2015;2:27768.
22. Brozek GM, Farnik M, Lawson J, Zejda JE. Underdiagnosis of childhood asthma: A comparison of survey estimates to clinical evaluation. Int J Occup Med Environ Health. 2013;26(6):900-909.

23. Stupka E, deShazo R. Asthma in seniors: Part 1. Evidence for underdiagnosis, undertreatment, and increasing morbidity and mortality. Am J Med. 2009;122(1):6-11.

24. Cagney M, MacIntyre CR, McIntyre PB, Peat J. Childhood asthma diagnosis and use of asthma medication. Aust Fam Physician. 2005;34(3):193-196.

25. LindenSmith J, Morrison D, Deveau C, Hernandez P. Overdiagnosis of asthma in the community. Can Respir J. 2004;11(2):111-116.

26. Aaron SD, Vandemheen KL, Boulet LP, et al. Overdiagnosis of asthma in obese and nonobese adults. CMAJ. 2008;179(11):1121-1131

27. Cave AJ, Atkinson LL. Asthma in preschool children: a review of the diagnostic challenges. J Am Board Fam Med. 2014;27(4):538-548.

28. Van Sickle D, Magzamen S, Maenner MJ, Crane J, Corden TE. Variability in the labeling of asthma among pediatricians. PLoS One. 2013;8(4):e62398.

29. Bousquet J, Heinzerling L, Bachert C, et al. Practical guide to skin prick tests in allergy to aeroallergens. Allergy. 2012;67(1):18-24.

30. Bisaccioni C, Aun MV, Cajuela E, Kalil J, Agondi RC, Giavina-Bianchi P. Comorbidities in severe asthma: frequency of rhinitis, nasal polyposis, gastroesophageal reflux disease, vocal cord dysfunction and bronchiectasis. Clinics. 2009;64(8):769-773.

31. Stirling RG, Chung KF. Severe asthma: definition and mechanisms. Allergy. 2001;56(9):825-840.

32. Peters SP, Ferguson G, Deniz Y, Reisner C. Uncontrolled asthma: a review of the prevalence, disease burden and options for treatment. Respir Med. 2006;100(7):1139-1151.

33. Haughney J, Price D, Kaplan A, et al. Achieving asthma control in practice: understanding the reasons for poor control. Respir Med. 2008;102(12):1681-1193.

34. Myers TR. Guidelines for asthma management: a review and comparison of 5 current guidelines. Respir Care. 2008;53(6):751-767.

35. Price D, Fletcher M, van der Molen T. Asthma control and management in 8,000 European patients: the REcognise Asthma and LInk to Symptoms and Experience (REALISE) survey. NPJ Prim Care Respir Med. 2014;12(24):14009.

36. Luskin AT, Chipps BE, Rasouliyan L, Miller DP, Haselkorn T, Dorenbaum A. Impact of asthma exacerbations and asthma triggers on asthmarelated quality of life in patients with severe or difficult-to-treat asthma. J Allergy Clin Immunol Pract. 2014;2(5):544-552.e1-e2.

37. Miller MK, Lee JH, Miller DP, Wenzel SE; TENOR Study Group. Recent asthma exacerbations: a key predictor of future exacerbations. Respir Med. 2007;101(3):481-489.

38. Dougherty RH, Fahy JV. Acute exacerbations of asthma: epidemiology, biology and the exacerbation-prone phenotype. Clin Exp Allergy. 2009;39(2):193-202.

39. Royal College of Physicians; National Review of Asthma Deaths; 2014. Why asthma still kills: the National Review of Asthma Deaths (NRAD); Confidential Enquiry Report. Available from: https://www.rcplondon. ac.uk/projects/outputs/why-asthma-still-kills. Accessed January 18, 2017.

40. Colice G, Martin RJ, Israel E, et al. Asthma outcomes and costs of therapy with extrafine beclomethasone and fluticasone. J Allergy Clin Immunol. 2013;132(1):45-54.

41. Zhang L, Prietsch SO, Ducharme FM. Inhaled corticosteroids in children with persistent asthma: effects on growth. Cochrane Database Syst Rev. 2014;(7):CD009471.

42. Broersen LH, Pereira AM, Jørgensen JO, Dekkers OM. Adrenal insufficiency in corticosteroids use: systematic review and meta-analysis. $J$ Clin Endocrinol Metab. 2015;100(6):2171-2180.

43. Weatherall M, Clay J, James K, Perrin K, Shirtcliffe P, Beasley R. Dose-response relationship of inhaled corticosteroids and cataracts: a systematic review and meta-analysis. Respirology. 2009;14(7): 983-990. 
44. Cumming RG, Mitchell P, Leeder SR. Use of inhaled corticosteroids and the risk of cataracts. N Engl J Med. 1997;337(1):8-14.

45. Suissa S, Kezouh A, Ernst P. Inhaled corticosteroids and the risks of diabetes onset and progression. Am J Med. 2010;123(11):1001-1006.

46. Packe GE, Douglas JG, McDonald AF, Robins SP, Reid DM. Bone density in asthmatic patients taking high dose inhaled beclomethasone dipropionate and intermittent systemic corticosteroids. Thorax. 1992;47(6):414-417.

47. Kelly HW, Van Natta ML, Covar RA, et al. Effect of long-term corticosteroid use on bone mineral density in children: a prospective longitudinal assessment in the childhood Asthma Management Program (CAMP) study. Pediatrics. 2008;122(1):e53-e61.

48. McKeever T, Harrison TW, Hubbard R, Shaw D. Inhaled corticosteroids and the risk of pneumonia in people with asthma: a case-control study. Chest. 2013;144(6):1788-1794.

49. Sweeney J, Patterson CC, Menzies-Gow A, et al. Comorbidity in severe asthma requiring systemic corticosteroid therapy: cross-sectional data from the Optimum Patient Care Research Database and the British Thoracic Difficult Asthma Registry. Thorax. 2016;71(4):339-346.

50. Lougheed MD, Leniere C, Ducharme FM, et al. Canadian Thoracic Society 2012 guideline update: diagnosis and management of asthma in preschoolers, children and adults: executive summary. Can Respir J. 2012;19(6):e81-e88.

51. Dahl R. Systemic side effects of inhaled corticosteroids in patients with asthma. Respir Med. 2006;100(8):1307-1317.

52. Thomas M, Murray-Thomas T, Fan T, Williams T, Taylor S. Prescribing patterns of asthma controller therapy for children in UK primary care: a cross-sectional observational study. BMC Pulm Med. 2010;10:29.

53. Thomas M, Turner S, Leather D, Price D. High-dose inhaled corticosteroid use in childhood asthma: an observational study of GP prescribing. Br J Gen Pract. 2006;56(531):788-790.

54. Buhl R, Marco AG, Cohen D, Canonica GW. Eligibility for treatment with omalizumab in Italy and Germany. Respir Med. 2014;108(1):50-56.

55. Busse W, Corren J, Lanier BQ, et al. Omalizumab, anti-IgE recombinant humanized monoclonal antibody, for the treatment of severe allergic asthma. J Allergy Clin Immunol. 2001;108(2):184-190.

56. Holgate ST, Chuchalin AG, Hebert J, et al. Efficacy and safety of a recombinant anti-immunoglobulin E antibody (omalizumab) in severe allergic asthma. Clin Exp Allergy. 2004;34(4):632-638.

57. Soler M, Matz J, Townley R, et al. The anti-IgE antibody omalizumab reduces exacerbations and steroid requirement in allergic asthmatics. Eur Respir J. 2001;18(2):254-261.

58. Molimard M, Buhl R, Niven R, et al. Omalizumab reduces oral corticosteroid use in patients with severe allergic asthma: real-life data. Respir Med. 2010;104(9):1381-1385.

59. Brodlie M, McKean MC, Moss S, Spencer DA. The oral corticosteroidsparing effect of omalizumab in children with severe asthma. Arch Dis Child. 2012;97(7):604-609.

60. Walsh GM. An update on biologic-based therapy in asthma. Immunotherapy. 2013;5(11):1255-1264.

61. Murphy KR, Meltzer EO, Blaiss MS, Nathan RA, Stoloff SW, Doherty DE. Asthma management and control in the United States: results of the 2009 Asthma Insight and Management survey. Allergy Asthma Proc. 2012;33(1):54-64.

62. Zeiger RS, Heller S, Mellon MH, Wald J, Falkoff R, Schatz M. Facilitated referral to asthma specialist reduces relapses in asthma emergency room visits. J Allergy Clin Immunol. 1991;87(6):1160-1168.

63. Aragona E, Wang J, Scheckelhoff T, et al. Asthma specialty clinics decrease emergency department visits in inner-city children hospitalized for asthma exacerbation. Am J Respir Crit Care Med. 2014;189: A3838.

64. Fang X, Li S, Gao L, Zhao N, Wang X, Bai C. A short-term educational program improved physicians' adherence to guidelines for COPD and asthma in Shanghai. Clin Transl Med. 2012;1(1):13.

65. Pinnock H, Holmes S, Levy ML, McArthur R, Small I; Group UKGPA. Knowledge of asthma guidelines: results of a UK General Practice Airways Group (GPIAG) web-based 'Test your Knowledge' quiz. Prim Care Respir J. 2010;19(2):180-184.
66. Plaza V, Bolivar I, Giner J, et al. Opinión, conocimientos y grado de seguimiento referidos por los profesionales sanitarios españoles de la Guía Española para el Manejo del Asma (GEMA). Proyecto GEMATEST [Knowledge of and attitudes and adherence to the Spanish Guidelines for Asthma Management (GEMA) among Spanish health care professionals: the GEMA test Project]. Arch Bronconeumol. 2008;44(5):245-251. Spanish.

67. Sun YH, Eun BW, Sim SY, et al. Poor adherence and reasons for nonadherence to the asthma guidelines among pediatricians in Korea. Asian Pac J Allergy Immunol. 2010;28(2-3):147-154.

68. Wisnivesky JP, Lorenzo J, Lyn-Cook R, et al. Barriers to adherence to asthma management guidelines among inner-city primary care providers. Ann Allergy Asthma Immunol. 2008;101(3):264-270.

69. Lugtenberg M, Zegers-van Schaick JM, Westert GP, Burgers JS. Why don't physicians adhere to guideline recommendations in practice? An analysis of barriers among Dutch general practitioners. Implement Sci. 2009;4:54.

70. Cabana MD, Lewis TC. Improving physician adherence to asthma guidelines. J Clin Outcomes Manage. 2001;8(3):35-46.

71. Wechsler ME. Managing asthma in primary care: putting new guideline recommendations into context. Mayo Clin Proc. 2009;84(8):707-717.

72. Kang MK, Kim BK, Kim TW, et al. Physicians' preferences for asthma guidelines implementation. Allergy Asthma Immunol Res. 2010;2(4):247-253.

73. Elward K, Blackburn B, Peterson LE, Greenawald M, Hagen MD. Improving quality of care and guideline adherence for asthma through a group self-assessment module. J Am Board Fam Med. 2014;27(3):391-398.

74. Okelo SO, Butz AM, Sharma R, et al. Interventions to modify health care provider adherence to asthma guidelines: a systematic review. Pediatrics. 2013;132(3):517-534.

75. Lugtenberg M, Burgers JS, Han D, Westert GP. General practitioners' preferences for interventions to improve guideline adherence. $J$ Eval Clin Pract. 2014;20(6):820-826.

76. Mehrotra A, Forrest CB, Lin CY. Dropping the baton: specialty referrals in the United States. Milbank Q. 2011;89(1):39-68.

77. Wahabi HA, Alziedan RA. Reasons behind non-adherence of healthcare practitioners to pediatric asthma guidelines in an emergency department in Saudi Arabia. BMC Health Serv Res. 2012;12:226.

78. Bodenheimer T. Coordinating care - a perilous journey through the health care system. N Engl J Med. 2008;358(10):1064-1071.

79. Mault S, McDonough B, Currie P, Burhan H. Reasons offered for nonattendance at a difficult asthma clinic. Thorax. 2012;67(Suppl 2):A187.

80. Barnett ML, Song Z, Landon BE. Trends in physician referrals in the United States, 1999-2009. Arch Intern Med. 2012;172(2):163-170.

81. Royal College of Physicians; 2003. Allergy: the unmet need; A blueprint for better patient care. Available from: http://www.bsaci.org/pdf/ allergy_the_unmet_need.pdf. Accessed January 18, 2017.

82. American College of Allergy Asthma and Immunology. Asthma management and the allergist: better outcomes at lower cost. Allergist. 2008:1-31.

83. Erickson S, Tolstykh I, Selby JV, Mendoza G, Iribarren C, Eisner MD. The impact of allergy and pulmonary specialist care on emergency asthma utilization in a large managed care organization. Health Serv Res. 2005;40(5 Pt 1):1443-1465.

84. Mahr TA, Evans R 3rd. Allergist influence on asthma care. Ann Allergy. 1993;71(2):115-120.

85. Schatz M, Zeiger RS, Mosen D, et al. Improved asthma outcomes from allergy specialist care: a population-based cross-sectional analysis. $J$ Allergy Clin Immunol. 2005;116(6):1307-1313.

86. Janson S, Weiss K. A national survey of asthma knowledge and practices among specialists and primary care physicians. J Asthma. 2004;41(3):343-348.

87. Wark PA, Hew M, Maltby S, McDonald VM, Gibson PG. Diagnosis and investigation in the severe asthma clinic. Expert Rev Respir Med. 2016;10(5):491-503.

88. National Asthma Council Australia. The Australian Asthma Handbook. 2015. Available from: http://www.asthmahandbook.org.au. Accessed January 18, 2017. 
Journal of Asthma and Allergy

The Journal of Asthma and Allergy is an international, peer-reviewed open access journal publishing original research, reports, editorials and commentaries on the following topics: Asthma; Pulmonary physiology; Asthma related clinical health; Clinical immunology and the immunological basis of disease; Pharmacological interventions and new therapies. This journal is included in PubMed. The manuscript management system is completely online and includes a very quick and fair peer-review system, which is all easy to use. Visit http://www. dovepress.com/testimonials.php to read real quotes from published authors.

Submit your manuscript here: https://www.dovepress.com/journal-of-asthma-and-allergy-journal 